\title{
SHEAR STRESS AT THE BASE OF A RIGIDLY ROTATING GIRQUE GLACIER
}

\author{
By J. WeErtman \\ (Department of Materials Science, Department of Geological Sciences and Materials Research \\ Center, Northwestern University, Evanston, Illinois 6o20 I, U.S.A.)
}

\begin{abstract}
The value of the basal shear stress is derived for two-dimensional and three-dimensional cirque glaciers. It is assumed that a cirque glacier moves primarily by a rigid-body rotation over a bed of cylindrical or spherical shape. In the region of maximum ice thickness the new value of the basal shear stress is only about one half that derived from equations in common use in the literature. The new expression for the basal shear stress of a cirque glacier is used to correct a data point in Paterson's recent compilation of measured sliding velocities and basal shear stresses of glaciers.
\end{abstract}

RÉsumé. Cisaillement à la base d'un glacier de cirque subissant une rotation à la manière d'un corps solide. La valeur de l'effort de cisaillement à la base est calculée pour des glaciers de cirques considérés comme ayant 2 dimensions et 3 dimensions. On admet qu'un glacier de cirque se meut en première approximation comme un corps solide en rotation sur un lit de forme cylindrique ou sphérique. Dans la région d'épaisseur maximum de la glace la nouvelle valeur de l'effort de cisaillement à la base est seulement d'environ la moitié de celui tiré des équations communément employées dans la littérature. La nouvelle expression pour l'effort de cisaillement à la base d'un glacier de cirque est utilisée pour corriger une donnée dans une récente compilation de Paterson de mesures de vitesses de glissement et d'efforts de cisaillement à la base des glaciers.

Zusammenfassung. Scherspannung am Grunde eines starr rotierenden Kargletschers. Der Scherspannungswert am Grund wird für zwei- und dreidimensionale Kargletscher abgeleitet. Es wurde angenommen, dass die Bewegung eines Kargletschers primär der Rotation eines starren Körpers über ein zylindrisches oder sphärisches Bett entspricht. Im Gebiet der grössten Eismächtigkeit ist der neue Wert für die Scherspannung am Grunde nur halb so gross wie der, den man mit in der Literatur gebräuchlichen Gleichungen erhält. Der neue Ausdruck für die Grundscherspannung eines Kargletschers wird benutzt, um einen bestimmten Wert in Paterson's neuerer Berechnung von gemessenen Gleitgeschwindigkeiten und Grundscherspannungen von Gletschern zu korrigieren.

\section{Introduction}

Paterson (1970) has examined the published data on the measured sliding velocity of glaciers. He concluded that the existing data (seven measured sliding velocities and stresses listed in his table II and retabulated again in our Table I) lend no support to our equation (Weertman, I957, I964) for the sliding velocity of a glacier.

$$
u_{\mathrm{b}}=B S^{p} \tau^{m}
$$

Here $u_{\mathrm{b}}$ is the sliding velocity, $B$ is a constant, $S$ is a measure of the smoothness of the bed, $\tau$ is the basal shear stress, $p \approx 4$, and $m \approx 2$.

Paterson was careful to point out that the data compiled in his table II (and our Table I) do not disprove Equation (I). With one exception, the value of the smoothness $S$ was not measured. Paterson could only conclude that if it is assumed that the beds of all the glaciers figuring in his compilation have the same value of $S$, the data do not support a relationship of $u_{\mathrm{b}}$ being proportional to $\tau^{m}$. An observed failure of the relationship would not be surprising. For example, if $S$ varies from glacier to glacier (or from one region of a glacier to another region) over the relatively narrow range of a factor of 3 the sliding velocity predicted by Equation (I) for a given stress varies over two orders of magnitude. Obviously it is difficult to test Equation (I) without knowledge of $S$. (Moreover, theoretical predictions have been made that an abundance of melt water at the base of a glacier can change the sliding velocity markedly. Equation (I) takes no account of the effect of water flow at the bottom of a glacier.)

A plot of $u_{\mathrm{b}}$ versus $\tau$, done with values from Paterson's paper, is shown in Figure $\mathrm{I}$. (His paper contained no such plot.) The basal shear stress $\tau$ was estimated by the well-known equation

$$
\tau=\rho g h \sin \alpha
$$


where $\rho$ is the density of ice, $g$ is the gravitational acceleration, $h$ is the ice thickness, and $\alpha$ is the slope of the upper ice surface. This equation is valid for a two-dimensional glacier in which the longitudinal stress varies slowly as function of distance down the length of the glacier.

Figure I impressed me with the fact that only two of the data points really disagree strongly with the relationship in which $u_{\mathrm{b}}$ is proportional to $\tau^{m}$ for a constant value of $S$. The most striking "anomalous" data point of Figure I (identified by an arrow) was obtained from Vesl-Skautbreen. This glacier is a small cirque glacier. Its measured sliding velocity, $2.3 \mathrm{~m} \mathrm{a}^{-1}$, is unusually small for the relatively large basal shear stress of 1.9 bar estimated

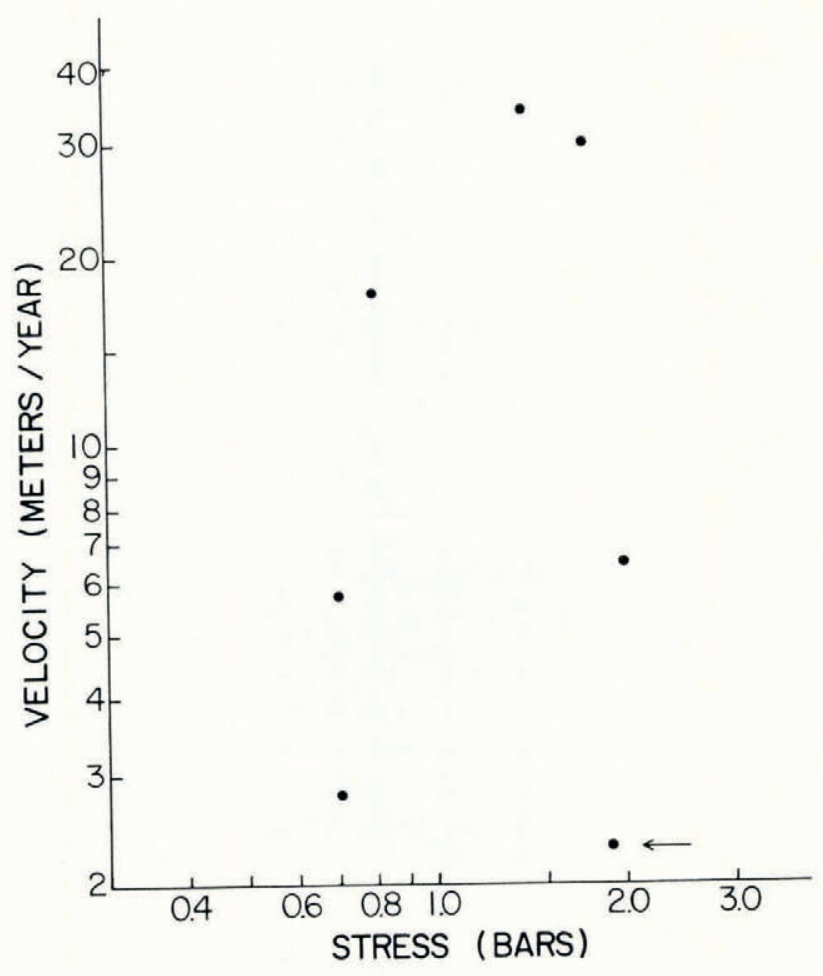

Fig. I. Plot of measured sliding velocity versus shear stress for data compiled by Paterson (I97o) and listed again in Table I. The arrow points to the datum point from Vesl-Skautbreen.

from Equation (2). An obvious question to ask is: Does Equation (2), when applied to a cirque glacier, seriously over-estimate the magnitude of the basal shear stress?

One correction to Equation (2) already exists in the literature. It is the "hydraulic radius" correction for the transverse cross-section of a valley glacier (Nye, i965). Equation (2) is changed to

$$
\tau=F \rho g h \sin \alpha
$$

where $F$ is a correction factor. A typical value for $F$ (Nye, I965) is 0.7. (For a two-dimensional glacier $F=$ I.)

Unfortunately, the use of Equation (3) to correct $\tau$ does not make the Vesl-Skautbreen data point any less unusual. All the stress values of the data points in Figure 2 are reduced 
by roughly the same amount $(30 \%)$ through the use of the correction factor $F$. If the VeslSkautbreen point is to be "fixed-up", a correction factor must be found which is significant for cirque glaciers but unimportant for valley glaciers.

The length of a cirque glacier is comparable to its maximum thickness. This fact suggests that a "longitudinal hydraulic radius" correction to the basal shear stress might be made for cirque glaciers. It is the purpose of this paper to derive this second correction factor.

\section{Basal shear stress of cirque glaciers}

The only cirque glacier whose movement and deformation have been investigated extensively is Vesl-Skautbreen (McCall, 1952, 1960; the various papers in the book edited by Lewis, r960). The results obtained on this glacier show that relatively little differential deformation occurs within the ice mass. The glacier moves essentially by a rigid-body rotation over a bed of approximately spherical shape.

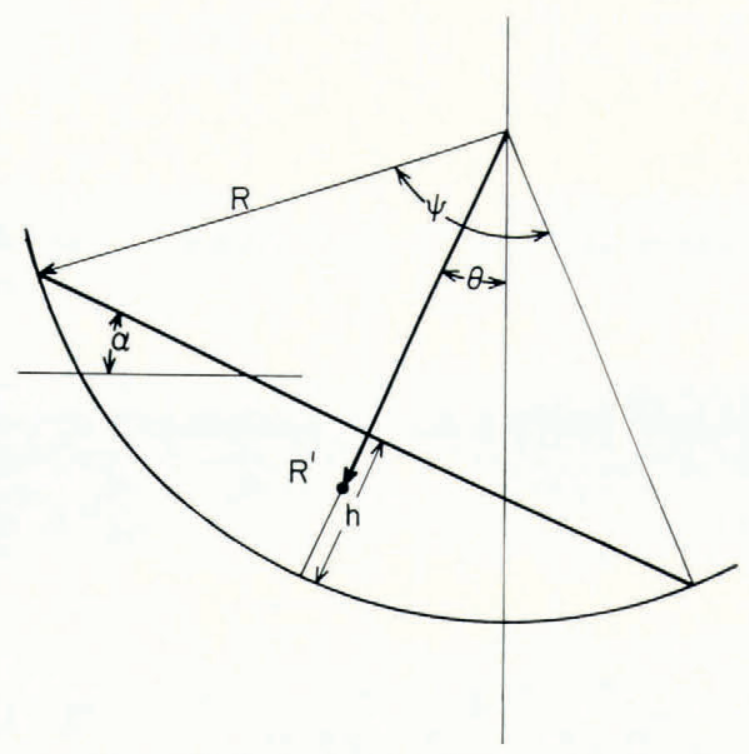

Fig. 2. Idealized cross-section of a cirque glacier.

Following McCall, let us idealize a cirque glacier to be as shown in Figure 2. Let a twodimensional cirque glacier rest on a bed of cylindrical shape and a three-dimensional cirque glacier on a bed of spherical shape. The radius of curvature of the bed is taken to be $R$. Let $R^{\prime}$ be the distance from the center of the cylinder or sphere which describes the bed to the center of gravity of the glacier. Let $\theta$ be the angle between the vertical and the direction of $R^{\prime}$. For a two-dimensional glacier let $\psi$ be the angle subtended by the glacier surface as shown in Figure 2. For a three-dimensional glacier let $\Omega$ be the solid angle subtended. The total mass of a three-dimensional glacier or the mass per unit length of a two-dimensional glacier is taken to be equal to $M$.

Assume that a cirque glacier moves primarily by a rigid body rotation about the center of the cylinder or sphere which describes its bed. The glacier must slide with approximately equal velocity at every point on its bed. The area of its bed is equal to $R \psi$ or $R^{2} \Omega$. If $\tau$ is the average shear stress acting across the bed, the work done during sliding when the glacier rotates through an angle $\delta \theta$, and thus slides by a distance $R \delta \theta$, is $\tau R^{2} \psi \delta \theta$ or $\tau R^{3} \Omega \delta \theta$. This 
change in energy must come from the decrease in gravitational energy. The change in gravitational energy is simply $g M R^{\prime} \sin \theta \delta \theta$. Equating the two energies gives

$$
\tau=(g M \sin \theta)\left(R^{\prime} \mid R\right) /(R \psi)
$$

for a two-dimensional glacier and

$$
\tau=(g M \sin \theta)\left(R^{\prime} \mid R\right) /\left(R^{2} \Omega\right)
$$

for a three-dimensional glacier.

When, as shown in Figure 2, the upper surface has a constant slope (the situation on Vesl-Skautbreen), the last two equations can be developed further. Let $h$ be the maximum thickness of the glacier (see Figure 2). The two-dimensional glacier has a mass per unit length equal to $\left(\rho R^{2} / 2\right)(\psi-\sin \psi)$. The thickness $h=R[\mathrm{I}-\cos (\psi / 2)]$ and $\theta=\alpha$. The ratio $R^{\prime} / R=\left[(4 / 3) \sin ^{3}(\psi / 2)\right] /(\psi-\sin \psi)$. Equation (4) reduces to

$$
\tau=\left[(\rho g h \sin \alpha)\left(R^{\prime} / R\right)(\psi-\sin \psi)\right] /[2 \psi\{\mathrm{I}-\cos (\psi / 2)\}] .
$$

When $\psi$ is less than I, Equation (6) approximates

$$
\tau \approx(2 / 3) \rho g h \sin \alpha\left(R^{\prime} \mid R\right) .
$$

For Vesl-Skautbreen $\psi=75 \cdot 3^{\circ}$ and thus $R^{\prime} \mid R=0.876$. Equation (6) reduces to

$$
\tau=(0.63)\left(R^{\prime} / R\right) \rho g h \sin \alpha=(0.55) \rho g h \sin \alpha
$$

when $\psi=75.3^{\circ}$.

A three-dimensional cirque glacier whose upper surface is planar and which makes a circular outline where the bed reaches the upper surface has a mass equal to $\left(\pi \rho h^{2} / 3\right)(3 R-h)$. The area of the bed in contact with ice is equal to $2 \pi R h$. Equation (5) reduces to

$$
\tau=(\mathrm{I} / 2) \rho g h \sin \alpha\left(R^{\prime} / R\right)\left(R^{\star} / R\right)
$$

where $\quad R^{\star} / R=\mathrm{I}-(h / 3 R) \quad$ and $\quad R^{\prime} / R=\sin ^{4}(\psi / 2) /\left\{4\left[\left(2 / 3-\cos (\psi / 2)+(\mathrm{I} / 3) \cos ^{3}(\psi / 2)\right]\right\}\right.$. The angle $\psi$ in this last expression is the angular opening of the cone which subtends the glacier surface and whose apex is at the center of the sphere whose surface is the bed. For Vesl-Skautbreen $h=50 \mathrm{~m}, R=240 \mathrm{~m}$, and $\psi \approx 75.3^{\circ}$. Thus $R^{\star} / R=0.93$ and $R^{\prime} / R=0.86$. Equation (9) reduces to

$$
\tau=0.40 \rho g h \sin \alpha
$$

for these values of $R^{\star} / R$ and $R^{\prime} \mid R$. The stress given by Equation (I0) is a factor 0.7 smaller than that given by Equation (8). Thus the transverse hydraulic radius correction for a three-dimensional cirque glacier is about the same as the correction found by Nye for an ordinary valley glacier.

The reader should note that, according to Equations (8) and (I0), the basal shear stress under the thickest part of a cirque glacier has a value which is only about one-half that estimated from the equations in use in the literature (that is, from Equations (2) and (3)). (Under the thinner parts the stress is larger than the value usually estimated.)

\section{Application}

Table I contains the value (labeled: corrected value) of the basal shear stress for VeslSkautbreen estimated through the use of Equation (8). (The value of $h$ given for this glacier in Table I actually is the maximum thickness of the glacier and can be used directly in Equation (8).)

In Figure 3 we have made a new plot of the sliding velocity $u_{\mathrm{b}}$ versus basal shear stress $\tau$ in which the corrected value of $u_{\mathrm{b}}$ and $\tau$ given in Table I are used. In Figure 3 and Table I we have added a sliding velocity value published since the completion of Paterson's paper. This sliding velocity point is that of Shreve and Sharp (1970). (It is an extrapolated value, as calculated by Paterson (private communication) in their Figure 6, from a depth of roo $\mathrm{m}$ 
Table I. Paterson's (1970) compilation of Published measurements of Surface velocity, Sliding velocity, ICE THICKNESS, SURFACE SLOPE AND BASAL SHEAR STRESS WITH AN ADDED CORREGTION AND AN ADDITION

$$
\begin{array}{cccccccc} 
& u_{\mathrm{s}} & u_{\mathrm{b}} & h & \alpha & \underset{b}{c} & \left(S / S_{0}\right) \dagger\left(S / S_{0}\right)_{+} & \text {Reference }
\end{array}
$$

Vesl-Skautbreen

$\begin{array}{rrrrrr}2.6 & 2.3 & 50 & 25 & \begin{array}{l}1.9 \\ 1.0\end{array} & 0.69 \\ 4.2 & 2.8 & 52 & 9 & 0.7 & 0.89 \\ 6.6 & 5.8 & 26 & 28 & 0.7 & 1.06 \\ 28.8 & 6.5 & 209 & 6.3 & 2.0 & 0.64 \\ 35 & 17.5 & 137 & 4.0 & 0.8 & 1.31 \\ 38.9 & 30 & 332 & 3.5 & 1.75 & 1.01 \\ 78 & 34 & 490 & 2.0 & 1.4 & 1.16 \\ & 17 & 120 & 10 & 1.85 & 0.80\end{array}$

$\begin{array}{ll}\text { McCall (i } 952) \\ 0.71 & \text { (corrected value) }\end{array}$

Tuyuksu

Blue

Athabasca

Grosser Aletschgletscher

Athabasca

Salmon

Blue*

* Not listed in Paterson's table.

$\dagger$ For line of Figure 3 with slope $=2.03$.

$\ddagger$ For line in Figure 3 with slope $=1.57$.

to the depth of the bed which is $120 \mathrm{~m}$.) The value of $\tau$ in Figure 3 is estimated either by Equation (2) or by Equation (8). It would be desirable to have another plot in which $\tau$ is estimated by either Equation (3) or Equation (Io). Not enough information exists to make this transverse hydraulic radius correction for all the shear stresses listed in Table I. The transverse hydraulic radius correction factor $F$ presumably would reduce most of the shear stresses listed in Table I by approximately $30 \%$. Most of the data points given in Figure 3 thus would be shifted to the left by roughly the same amount.

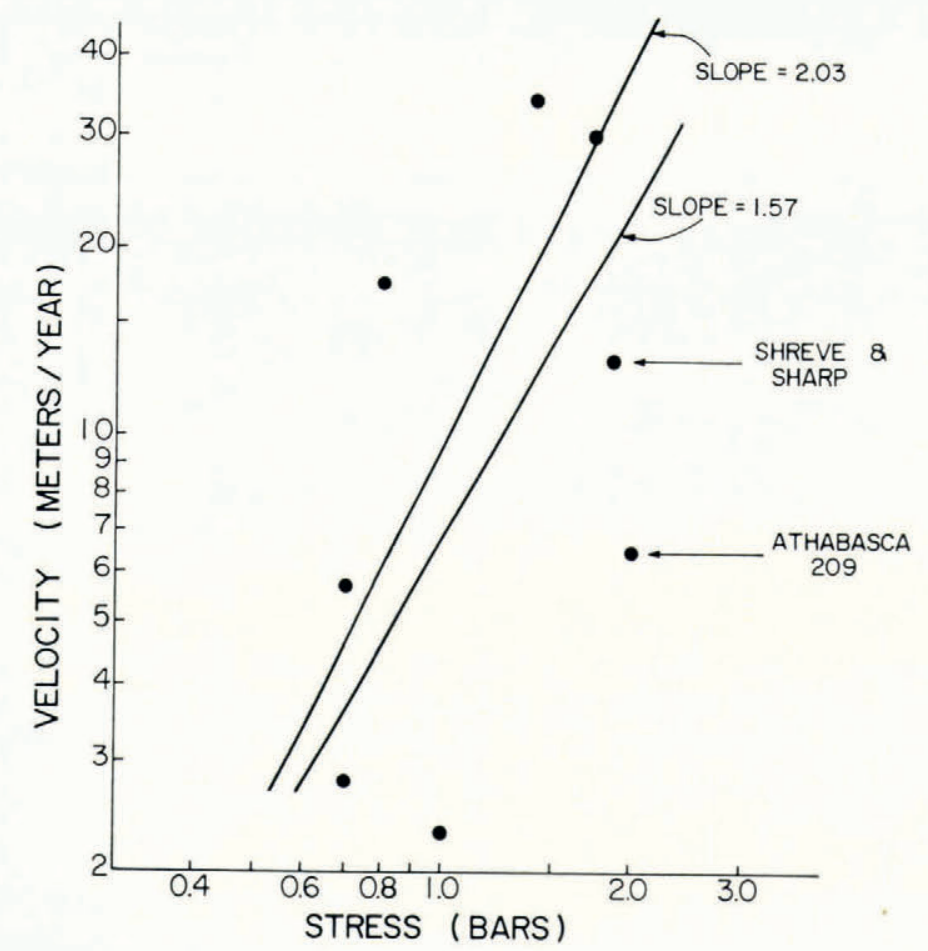

Fig. 3. Plot of measured sliding velocity versus shear stress for corrected data given in Table I. The straight lines are leastsquares fits to the data points described in the text. 
The two straight lines drawn through the data points in Figure 3 were fitted by the leastsquares technique. In calculating these lines it was assumed that the data point from Athabasca Glacier for $h=209 \mathrm{~m}$ is anomalous. Therefore this point was ignored in the calculation. The line whose slope $m$ is equal to 2.03 was calculated without the datum point of Shreve and Sharp; the other line was calculated with this point. The equation describing the lines is

$$
u_{\mathrm{b}}=u_{0}\left(\tau / \tau_{0}\right)^{m}
$$

where $u_{0}$ is always taken to equal $\mathrm{I} \mathrm{m} \mathrm{a}^{-1}$. It is to be understood that $\tau$ in Equation (I I) is calculated through use of either Equation (2) or (8). The constant $\tau_{0}=0.332$ bar for the line with slope $m=2.03$ in Figure 3. The standard error (defined by equation (9), p. I 295 of Rektorys, I 969 ) of the slope is equal to I.I 8 for this line. For the line of slope $m=\mathrm{I} .57$ in Figure 3 the constant $\tau_{0}=0.256$ bar and the error on $m$ is equal to 0.929. Student's $t$ test of significance (Rektorys, I969, p. 1273) on the regression coefficient (which is equal to $m$ ) gives $t=\mathrm{I} .72$ for the line of the slope $m=2.03$ and $t=\mathrm{I} .69$ for the slope $m=\mathrm{I} .57$ when these lines are compared to a slope $m=0$. Therefore, no significant relationship is found between sliding velocity and shear stress by this statistical test. (If the Vesl-Skautbreen, Shreve and Sharp's and the Athabasca Glacier $h=209 \mathrm{~m}$ data points are ignored the leastsquares straight line fit gives for Equation (I I) $u_{0}=\mathrm{I} \mathrm{m} \mathrm{a}{ }^{-1}, \tau_{0}=0.305 \mathrm{bar}$, and $m=2.13$ with a standard error for $m$ of 0.79 and $t=2.6 \mathrm{~g}$. A least-squares fit to all eight points of Figure 3 gives $u_{0}=\mathrm{I} \mathrm{m} \mathrm{a}{ }^{-1}, \tau_{0}=0.140$ bar, $m=\mathrm{I} .05 \pm 0.84$ and $t=\mathrm{I} .25$; a least-squares fit to all points in Figure $\mathrm{I}$ gives $u_{0}=\mathrm{I} \mathrm{m} \mathrm{a}{ }^{-1}, \tau_{0}=\mathrm{I} .76 \times \mathrm{IO}^{-3} \mathrm{bar}, m=0.33 \pm \mathrm{I} . \mathrm{OI}$, and $t=0.33$.)

The plot of the data shown in Figure 3 takes no account of the smoothness term $S$ in Equation (I). With one exception this term is not known for the data points. One can look at the question of the value of $S$ in the inverse sense. Suppose $S_{0}$ is the smoothness defined such that when $S=S_{0}$ a data point will lie exactly on the least-squares straight line. Table I lists the value of the ratio $S / S_{0}$, calculated for $p=4$, which is required to account for that fact each data point of Figure 3 does not lie exactly on the least-squares straight line. It can be seen that Equation (I) can account for the value of all the data points of Figure 3 if it is assumed that the ratio $S / S_{0}$ varies from glacier to glacier in the narrow range of $0.64 \leqslant S / S_{0} \leqslant$ I.3 I.

The reader, of course, will form his own judgement on just how much support the data plotted in Figure 3 and listed in Table I give to Equation (I).

\section{Acknowledgement}

I wish to thank Dr W. S. B. Paterson for pointing out numerous errors in earlier versions of this paper.

MS. received 23 June 1970 and in revised form 27 August 1970

\section{REFERENCES}

Borovinskiy, B. A., and Makarevich, K. G. 1959. Primeneniye elektrometrii pri izuchenii dvizheniya lednikov [Use of electrometry in studying movement of glaciers]. Vestnik Akademii Nauk Kazakhskoy SSR, 1959, No. 7, p. $45-50$.

Gerrard, J. A. F., and others. 1952. Measurement of the velocity distribution along a vertical line through a glacier, by J. A. F. Gerrard, M. F. Perutz and A. Roch. Proceedings of the Royal Society, Ser. A, Vol. 213, No. I I I 5 , p. $546-58$.

Kamb, W. B., and LaChapelle, E. R. 1964. Direct observation of the mechanism of glacier sliding over bedrock.

Journal of Glaciology, Vol. 5, No. 38, p. ${ }^{159-72 .}$
Lewis, W. V., ed. 1960. Investigations on Norwegian cirque glaciers. London, Royal Geographical Society. (R.G.S. Research Series, No. 4.) 
McCall, J. G. 1952. The internal structure of a cirque glacier: report on studies of the englacial movements and temperatures. Fournal of Glaciology, Vol. 2, No. 12, p. 122-31.

McCall, J. G. 1960. The flow characteristics of a cirque glacier and their effect on glacial structure and cirque formation. (In Lewis, W. V., ed. Investigations on Norwegian cirque glaciers. London, Royal Geographical Society, p. 39 -62. (R.G.S. Research Series, No. 4.))

Mathews, W. H. r959. Vertical distribution of velocity in Salmon Glacier, British Columbia. Journal of Glaciology, Vol. 3, No. 26, p. 448-54.

Nye, J. F. ${ }^{1965}$. The flow of a glacier in a channel of rectangular, elliptic or parabolic cross-section. Fournal of Glaciology, Vol. 5, No. 41, p. 66r-9o.

Paterson, W. S. B. 1970. The sliding velocity of Athabasca Glacier, Canada. Journal of Glaciology, Vol. 9, No. 55, p. $55^{-63}$.

Rektorys, K., ed. I969. Survey of applicable mathematics. Cambridge, Mass., M.I.T. Press.

Savage, J. C., and Paterson, W. S. B. I963. Borehole measurements in the Athabasca Glacier. Fournal of Geophysical Research, Vol. 68, No. 15, p. 4521-36.

Shreve, R. L., and Sharp, R. P. 1970. Internal deformation and thermal anomalies in lower Blue Glacier, Mount Olympus, Washington, U.S.A. Journal of Glaciology, Vol. 9, No. 55, p. 65-86.

Vilesov, E. N. 1961. Temperature of ice in the lower parts of the Tuyuksu glaciers. Union Géodésique et Géophysique Internationale. Association Internationale d'Hydrologie Scientifique. Assemblée générale de Helsinki, 25-7-6-8 1960 . Commission des Neiges et Glaces, p. 31 $3-24$.

Weertman, J. 1957. On the sliding of glaciers. Journal of Glaciology, Vol. 3, No. 21, p. 33-38.

Weertman, J. r964. The theory of glacier sliding. Fournal of Glaciology, Vol. 5, No. 39, p. $287-303$. 